\title{
ANALISIS KINERJA PEGAWAI BAGIAN PELAYANAN \\ DI PT. POS INDONESIA (PERSERO) KANTOR POS SUBANG \\ ${ }^{1}$ Engkus , ${ }^{2}$ Nadiya Ulfah
}

${ }^{1}$ Fakultas Ilmu Sosial dan Ilmu Politik, UIN Sunan Gunung Djati Bandung; engkus@uinsgd.ac.id

${ }^{2}$ Fakultas Ilmu Sosial dan Ilmu Politik, UIN Sunan Gunung Djati Bandung; nadiyaulfa3@gmail.com

\begin{abstract}
The research focused on the performance of employees in the service section. The main problem in this study is that there are still employees who do not respond to the procedures set at the Subang Post Office. The purpose of this study is to analyze how the performance of employees in the service sector. The research method used in this study is a qualitative approach with descriptive method. Data collection techniques used in the form of observation techniques, interviews and literature. The results showed that the quantity of work done by employees in doing work not in accordance with the predetermined target, the quality of work results of employees at the Subang Post Office could not be said to be good, the time period that can be achieved in doing work is quite fast and quite good, in terms of attendance it is still not good because there are still late employees in doing work, and the ability to work with the leaders or fellow employees that has been established is good. And the conclusions of this study are that the employees in the Subang Post Office service are not optimal.
\end{abstract}

Keywords: Public Service, Employee Performance, Leadership, Human Resource Development 


\section{Pendahuluan}

Setiap instansi baik pemerintahan maupun perusahaan mempunyai tujuan yang akan dicapai di masa mendatang, untuk memuwujudakan tujuan tersebut salah satu faktornya yaitu kinerja pegawai. Sebelum lebih jauh membahas kinerja pegawai, perlu dipahami bahwa kinerja ini bukanlah suatu karakteristik seseorang baik itu bakat maupun kemampuan, melainkan sebuah perwujudan dari bakat maupun kemampuan tersebut (Sedermayanti, 2001). Secara sederhana, Noe (2006), Mathis dan Jackson (2006) berpendapat bahwa kinerja ini ialah apapun yang dilaksanakan atau tidak dilaksanakan oleh pegawai dalam sebuah lembaga. Adapun Arifin (2004) melihat bahwa kinerja merupakan produk dari sebuah kemampuan dan motivasi seseorang. Sedangkan bagi Yuniarsih dkk (2008) memandang bahwa kinerja adalah prestasi aktual yang ditunjukkan seseorang atau lembaga setelah menjalankan segala proses yang menjadi bagian tugas dan fungsinya. Kinerja ini merupakan serangkaian hasil yang didapatkan seorang pegawai pada periode yang telah ditentukan, dan juga buka berkaitan dengan karakter maupun sikap pegawai tersebut (Keban, 2004).

Kinerja pegawai perlu diperhatikan oleh pemimpin instansi karena kinerja pegawai sangat berpengaruh terhadap kinerja instansi secara keseluruhan. Selain itu juga harus tetap memperhatikan tingkat kepuasan pegawai yang melaksanakan kegiatan. Untuk menciptakan sitem kerja yang baik maka instansi dalam menjalan-kan fungsinya merupakan suatu tindakan dalam menyempurnakan tata kerja dan pengaruh kepada peningkatan kinerja pegawai. Kinerja pegawai ini pun penting untuk bisa diukur, sehingga perlu sejumlah indikator yang diantaranya adalah kejelasan, fokus, relevan, realistis, kontingensi, dapat dikontrol, dapat dibandingkan, dan holistik (Mahmudi, 2005). Sedangkan Mcdonald dan Lawton dalam Ratminto (2005) berpendapat bahwa kinerja pegawai ini dapat dikur dari 
ukuran yang berorientasi pada hasil bukan proses, sebuah keadaan yang memperlihatkan ketercapaian perbandingan terbaik antara input dan output dalam melaksanakan pelayanan publik, dan ketercapaian tujuan yang telah ditentukan sebelumnya baik itu berbentuk target serta sasaran lembaga dalam jangka pendek dan jangka panjang.

Kinerja pegawai melihat sejauh mana pegawai dapat menjalankankan tugas yang diperintahkan kepadanya dengan baik sesuai dengan perencanaan, sehingga mendapatkan hasil yang memuaskan (Umam, 2014). Dalam rangka memperbaiki kinerja pegawai, maka dibutuhkan pegawai yang dapat menjalankan perkerjaannya secara efektif dan efisien. Ini berimplikasi pada usaha untuk menghemat waktu dalam melaksanakan tugasnya, serta memperbaiki disiplin kerja terutama dalam melakukan pekerjaan yang sesuai dengan aturan dan ketentuan yang berlaku.

Dalam upaya pencapaian kinerja yang lebih baik, maka diperlukan pegawai yang memiliki etos kerja baik, disiplin, dan akuntabel dalam setiap aktivitas pekejaannya (Suhendi \& Anggara, 2010). Dengan demikian, kinerja yang baik lebih menekankan pada perilaku masing-masing pegawai dalam mendukung keberhasilan pelaksanaan tugas, karena kinerja pegawai akan mempengaruhi terhadap kinerja instansinya (Anggara, 2016). Dilihat dari seberapa banyak mereka memberikan kontribusi kepada instansi tersebut, maka setiap pekerjaan tentu mempunyai beberapa karakteristik atau dimensi pekerjaan yang jelas, tegas, dan spesifik.

Pada pokoknya sebuah kinerja itu menunjukkan pada apa yang dihasilkan dari tugas dan fungsi suatu pekerjaan atau apa yang terjadi setelah pekerjaan itu dilakukan (outcome). Jika dilihat lebih mendalam tentang apa yang terjadi pada sebuah pekerjaan maka disitu ada suatu proses pengolahan input menjadi output. Dalam mengukur suatu hasil kinerja individu, 
maka itu harus berdasarkan pada suatu pedoman standar yang jelas dan juga tertulis. Hal tersebut didasari karena sebuah kinerja memiliki komponen kompetensi, kualifikasi, dan produktivitas hasil, maka kinerja sangat tergantung pada tingkat kapasitas personal setiap pegawai dalam mendukung tujuan organisasi (Umam, 2012). Sedangkan bagi Selim dan Woodward dalam Ratminto (2005), kinerja bisa diukur berdasarkan indikator-indikator seperti beban kerja, ekonomi, efektivitas, efisiensi, dan keadilan. Sementara Dwiyanto (2002) berpendapat bahwa ada beberapa indikator penilaian kinerja, yaitu diantaranya adalah produktivitas (rasio antara masukan dan luaran), kualitas pelayanan (pemberian layanan pegawai kepada masyarakat yang berimplikasi pada kepuasan dan ketidak puasan), responsivitas (sikap organisasi dalam mengenali kebutuhan masyarakat, menyusun agenda pelayanan, dan mengembangkan sejumlah program pelayanan yang disesuaikan dengan kebutuhan masyarakat), responsibilitas (apakah pelaksanaan program lembaga dilakukan sesuai dengan prinsip-prinsip administrasi dan standar operasional kerja, dan akuntabilitas (kemampuan pegawai untuk bisa mempertanggung jawabkan hasil kerja yang dilakukan sesuai dengan tugas pokok dan fungsinya).

Bidang pelayanan merupakan bidang yang melakukan pelayanan kepada masyarakat dan juga bertanggung jawab melaksanakan pelayanan loket dengan standar layanan yang telah ditetapkan. Tugas utama dalam melakukan pekerjaan yaitu (1) Melakukan persiapan pembukaan layanan Pospay, Remittance, Ipos, dan GOL, (2) Melakukan pemrosesan transaksi lkayanan Pospay, Remittance, Ipos, dan GOL, (3) Melakukan konfirmasi transaksi Pospay, Remittance, Ipos, dan GOL ke publik sebelum melakukan enter untuk di print, (4) Meminta panjar uang ke kasir untuk transaksi pembayaran, (5) Melakukan amprah BPM, (6) Membuat neraca loket terpadu, (7) Melakukan penutupan layanan Pospay, Remittance, Ipos, dan GOL, (8) Melakukan penyetoran ke kasir. 
Dari tugas utama dalam melakukan pekerjaan bidang pelayanan tersebut maka kinerja sangat diperlukan karena dengan adanya kinerja pegawai maka tugas utama dalam melakukan pekerjaan tersebut maka pelaksanaan tugas di bidang layanan dapat terlaksana dalam melakukan layanan Pospay, Remittance, Ipos, dan GOL. Pegawai yang bertugas dibidang pelayanan adalah pihak yang sangat diharapkan dalam menopang pelayanan publik yang prima dan berkualitas. Pelayanan publik dapat dikategorikan prima karena ditentukan oleh sikap, perilaku, dan cara kerja para pegawai tersebut. Dengan kata lain pelayanan publik berkaitan erat dengan kinerja pegawai tersebut.

PT. Pos Indonesia (PERSERO) adalah sebuah perusahaan milik negara atau biasa disebut BUMN, yang bergerak dalam bidang jasa pengiriman surat. Selain itu juga sebagai salah satu instansi yang melayani masyarakat dalam dunia keuangan, fasilitas transfer uang, dan pembayaran tagihan, seperti listrik, air, dan telepon. Untuk menjadi sebuah perusahaan pengiriman terbaik di mata konsumen, maka PT. Pos Indonesia (PERSERO) harus dapat bersaing dengan perusahaan jasa pengiriman lainnya. Salah satu faktor utama dalam mewujudkan cita-cita tersebut, maka ketersediaan pegawai yang kompeten menjadi sebuah keharusan. Dengan demikian, sebaiknya kinerja pegawai khusus nya di bidang pelayanan harus lebih ditingkatkan lagi demi kenyamanan baik untuk masyarakat ataupun untuk instansinya itu sendiri.

Citra PT. Pos Indonesia (PERSERO) yang mulai menurun dimata masyarakat, membuat perusahaan ini mencari strategi lain agar kembali dilirik masyarakat, salah satu cara yang dilakukan adalah melalui pelatihan dan pengembangan guna untuk meningkat-kan kualitas sumber daya manusia atau pegawai yang ada. 
Hal penting yang menjadi tolak ukur masalah di PT. Pos Indonesia (PERSERO) Kantor Pos Subang yaitu kualitas, kuantitas, dan juga tingkat kehadiran pegawai dalam pekerjaan. Pada sisi kuantitas, sejauh mana pegawai dapat melakukan tugas utamanya sesuai dengan perintah atasan dan juga sesuai dengan program kerja yang telah ditetapkan. Pada kualitas yaitu bagaimana hasil dari pekerjaan yang telah dilakukan oleh pegawai tersebut sedangkan pada tingkat kehadiran pegawai yaitu seberapa banyak jumlah waktu tidak hadir tanpa izin dan juga keterlambatan ketika masuk kerja.

Penilaian kinerja yang digunakan PT. Pos Indonesia Indonesia (PERSERO) Kantor Pos Subang adalah KPI (Key Performance Indicator), berbentuk persentase target tercapai tidaknya kinerja yang dilakukan setiap tiga bulan sekali. Menurut keputusan Direksi PT. Pos Indonesia (PERSERO) Nomor: KD.23/DIRUT/0313 Tentang Sistem Manajemen Kinerja Individu, KPI (Key Performance Indicator) dalam melakukan penilaian kinerja. Sistem ini dipakai perusahaan untuk membantu mengukur dan menentukan keberhasilan kinerja terhadap sasaran setiap personal pegawai. KPI (Key Perfomance Indicator) mencakup kuantitas kerja, kualitas kerja dari tingkat kehadiran pegawai.

Sedangkan fenomena kinerja yang ada di bidang pelayanan PT. Pos Indonesia (PERSERO) Kantor Pos Subang belum seperti apa yang diharapkan, karena bisa dilihat dari pegawai yang kurang menanggapi prosedur yang telah ditetapkan oleh PT. Pos Indonesia (PERSERO) Kantor Pos Subang. Sehingga masih ada pegawai yang melanggar prosedur tersebut, hal ini bisa dilihat dari pegawai yang terlambat memasuki jam kerja.

Untuk menganalisis permasalahan tersebut, penelitian ini menggunakan sebuah teori kinerja pegawai dari Nawawi (2006:66), yang beberapa indikatornya mencakup lima unsur yaitu (1) kuantitas hasil kerja yang dicapai, (2) kualitas hasil kerja yang dicapai, (3) jangka 
waktu mencapai hasil kerja tersebut, (4) kehadiran dan kegiatan selama hadir di tempat kerja dan (5) kemampuan bekerjasama.

\section{Gambar 1.1}

\section{Paradigma Penelitian}

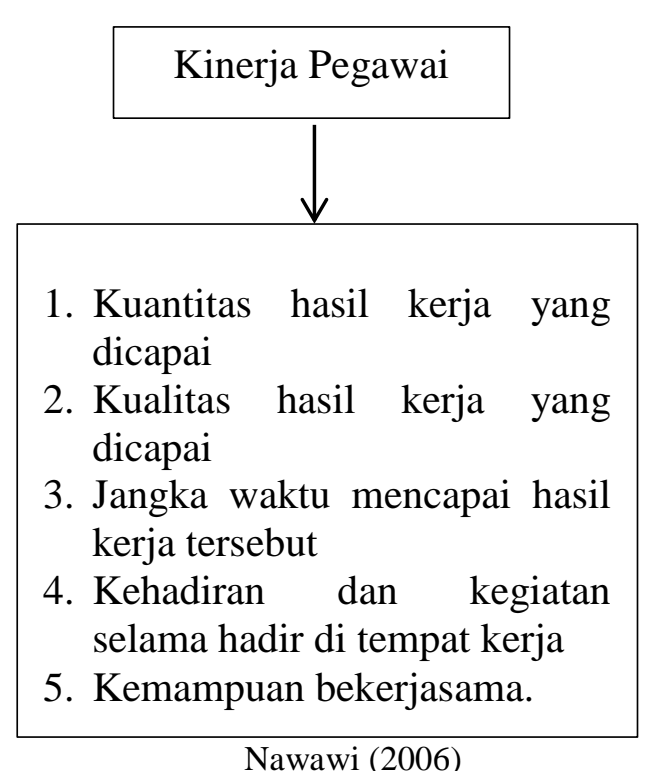

\section{Metode Penelitian}

Penelitian ini menggunakan pendekatan kualitatif dengan metode deskriptif. Dalam melakukan pengumpulan data, penelitian ini menggunakan teknik wawancara dan studi pustaka. Wawancara dilakukan untuk memperoleh data yang mendalam dari sejumlah informan, yang terdiri dari 8 orang yang terdiri dari Kepala Kantor Pos Subang, Manajer Bidang pelayana, Pegawai di Bidang Pelayanan dan 5 orang dari unsur masyarakat. Teknik studi pustaka digunakan untuk memperoleh dokumen dan arsip mengenai kinerja pegawai di Kantor Pos Subang. 


\section{Hasil dan Pembahasan}

1) Kuantitas hasil kerja yang dicapai

Dalam kuantitas kerja berarti disini karyawan harus berupaya dengan sekuat tenaga untuk mencapai hasil kerja yang sesuai dengan target. Ini artinya, karyawan harus selalu menyiapkan kondisi tubuh, kondisi perasaan dan juga kondisi pikiran yang bagus. Dalam mengoptimalkan kuantitas kerja sendiri tergantung pada niat da kemauan setiap pegawai, maka dari itu sebaiknya setiap karyawan memiliki motivasi yang kuat untuk menjadikan dirinya sebagai pribadi yang produktif, agar dapat mendapatkan kuantitas yang prima.

Kuantitas yang dimiliki oleh karyawan di bidang pelayanan Kantor Pos Subang, munurut informan yang menduduki jabatan sebagai Manajer Bidang Pelayanan, mengatakan bahwa:

“Kalau para pegawai masing-masing itu sudah diberi atau punya job desc dalam melaksanakan pekerjaan ataupun tugas kewajibannya suatu tugas, jadi pekerjaan itu menjadi terarah sehingga menghasilkan pekerjaan yang profesional.” (Sabtu, 09/03/2019 Pukul 09.30 Di Kantor Pos Subang).

Dari pernyataan tersebut bahwa setiap pegawai telah memili job desc masing-masing dalam melakukan suatu pekerjaan dan juga kewajibannya dalam bekerja maka dari itu pekerjaan akan terarah dan menghasilkan pekerjaan yang profesional. Selain itu juga penulis wewancarai masyarakat yang sedang melakukan transaksi di Kantor Pos Subang, menurut sodari Iis mengenai kuantitas hasil kerja pegawai di bidang pelayanan, mengatakan "Ramah, sopan dan bagus" (Sabtu, 09/03/2019 Pukul 10.53 Di Kantor Pos Subang), kemudian menurut informan mengenai kuantitas hasil kerja pegawai di bidang pelayanan, mengatakan “Ramah dan sopan" (Sabtu, 09/03/2019, Pukul 10.57), Di Kantor Pos Subang), kemudian 
menurut informan lainnya mengenai kuantitas hasil kerja pegawai di bidang pelayanan, mengatakan "Bagus" (Sabtu, 09/03/2019 Pukul 10.58) Di Kantor Pos Subang), selanjutnya menurut infoman bernama Radi mengenai kuantitas hasil kerja pegawai di bidang pelayanan, mengatakan "sejauh ini karena ga begitu sering, ya cukup" (Sabtu, 09/03/2019 Pukul 11.01 Di Kantor Pos Subang), dan menurut informan bernama Dedeh mengenai kuantitas hasil kerja pegawai di bidang pelayanan, mengatakan "Kemampuannya bagus" (Sabtu, 09/03/2019 Pukul 11.03 Di Kantor Pos Subang),

\section{Tabel 3.1}

Kinerja Produksi dan pendapatan Kantor Pos Subang Tahun 2015-2017

\begin{tabular}{|l|c|c|c|}
\hline \multirow{2}{*}{ Layanan } & \multicolumn{3}{|c|}{ Tahun } \\
\cline { 2 - 4 } & 2015 & 2016 & 2017 \\
\hline BPM, Surat Pos, dan Paket Pos & 23.376 & 26.175 & 21.651 \\
\hline Kirim Uang & 41,772 & 47,016 & 42,570 \\
\hline POSPAY & 88.436 & 93.781 & 101.657 \\
\hline
\end{tabular}

Sumber: Divisi Pelayanan PT. Pos Indonesia (PERSERO) Kantor Pos Subang

Dari tabel di atas menunjukan kinerja produksi Kantor Pos Subang pada BBM, surat pos, dan paket pos dan juga pengiriman uang mengalami penurunan setiap tahunnya, sedangkan POSPAY mengalami peningkatan setiap tahunnya.

Berdasarkan penyataan-pernyaataan di atas dapat dianalisa bahwa mengenai kuantitas hasil kerja pegawai di bidang pelayanan dalam melakukan pekerjaan belum sesuai dengan target yang telah ditentukan. 
2) Kualitas hasil kerja yang dicapai

Dalam kualitas kerja pegawai diharuskan memiliki mind set, keterampilan, pengetahuan serta niat baik untuk bekerja yang berkualitas, rapih dan juga teliti. Selain itu kuantitas juga bisa dilihat dari sejuah mana hasil pekerjaan yang dilakukan, usaha-usaha apa saja yang dilakukan untuk meningkatkan kualitas pekerjaan, dan apakah usaha tersebut membuahkan hasil dalam peningkatan kualitas kerja pegawai. Sama seperti dengan kuantitas, dalam mengoptimalkan kualitas kerja sendiri tergantung pada niat dan kemauan setiap pegawai, maka dari itu sebaiknya setiap karyawan memiliki motivasi yang kuat untuk menjadikan dirinya sebagai pribadi yang produktif, agar dapat mendapatkan kualitas yang prima.

Berikut penulis lampirkan hasil wawancara penulis dengan beberapa informan. Kualitas yang dimiliki oleh karyawan di bidang pelayanan Kantor Pos Subang, munurut informan yang menduduki jabatan sebagai Kepala Kantor Pos Subang, mengatakan bahwa:

"Kita di pelayanan ada tolak ukur, dalam hal di sini ada dua fungsi yaitu melayani dan menjual, di bagian pelayanan ini dia selain melayani adalah menjual. Melayaninya dengan seperti apa tentunya ada etika, estetikanya seperti apa dari mulai penampilan, dari mulai berinteraksi, kemudian bertransaksi. Nah dari isi penjualan, dari isi penjualan itu kan ada transaksi. Jadi, bisa dilihat tolak ukur nya kalo keberhasilan suatu bagian itu ada dimana dapat menghasilkan hasil jual yang lebih tinggi dari Hari ke Hari, dan seterusnya, jadi ada pengingkatan disitu. Nah itu menjadi tolak ukur atau suatu keberhasilan dari suatu bagian pelayanan. Jadi, ada ketentuan atau aturan yang membatasi atau yang mengatur pelayanan dan penjualan, adapun hal-hal yang terjadi di luar ketentuan yang berlaku itu selalu dikomunikasian dengan atasan. Kalo peran aktif tuh gini kita bisa melihat suatu bagian contohnya tadi di bagian pelayanan. Di pelayanan itu aktif dari sisi intelnal pertama, selalu mengevaluasi apa yang dihasilkan hari ini untuk ditingkatkan di hari berikutnya. Kemudian, mengevaluasi juga pekerjaan-pekerjaan yang ada di bawahannya. Misalkan gini, hari ini mendapatkan 10, besok harus mendapatkan 15, nah cara meningkatkan 5 ini dan cara keaktifan kepala bagian atau manager dibagian tersebut adalah dia bisa mengevaluasi dan melihat apa yang telah dilakukan oleh staffstaffnya kemaren kemudian apa yang akan dilakukan oleh staff-staffnya di hari ini bisa meningkatkan transakasi atau peningkatkan penjualan. Jadi, peran aktif di sini adalah mengevaluasi." (Rabu, 25/03/2109 Pukul 08.17 Di Kantor Pos Subang). 
Dari pernyataan di atas bahwa Kualitas yang dimiliki oleh karyawan di bidang pelayanan Kantor Pos Subang yaitu terdapat dua fungsi di bagian pelayanan yaitu melayani dan menjual. Dalam hal melayani tentunya ada etika dan juga estetik seperti penampilan, berinteraksi, dan juga bertransaksi. Dalam mengambil keputusan tentunya berkaitan dengan pekerjaan karena terdapat ketentuan yang mengatur pelayanan dan penjualan, jika ada hal yang terjadi di luar ketentuan yang berlaku makan akan dimusyawarahkan dengan atasan. Peran aktif yang dilakukan oleh pegawai yaitu bisa dilihat dari apa yang dilakukan oleh pegawai untuk meningkatkan hasil jual dihari berikutnya yang telah dievaluasi oleh manajer di hari ini.

Kualitas yang dimiliki oleh karyawan di bidang pelayanan Kantor Pos Subang, munurut informan yang menduduki jabatan sebagai Manajer Bidang Pelayanan, mengatakan bahwa:

"Dari hasil kerja tingkat pencapaiannya atau baik individu hasil kerja seseorang harus ada dari sasaran tugas, harus dilaksanakan dalam kurun waktu tertentu sehingga pencapaian kerja dapat menghasilkan kerja yang memuaskan. Iya kalo ibu sebagai manajer dalam mengambil keputusan selalu berhubungan dengan masalah pekerjaan tidak akan menyangkutkan atau berhubungan dengan masalah pribadi ataupun masalah keluarga karena tidak ada kaitannya ya. Seseorang manajer harus tegas dalam mengambil keputusan agar tidak terjadi keragu-raguan pada staff sehingga staff pun akan merasa bertanggung jawab atas apa yang sudah dikerjakan. Pegawai atau staf dalam mengerja-kan pekerjaan harus tuntas sehingga dapat menghasil-kan kerja yang memuaskan, saling berperan aktif satu dan yang lainnya, sehingga pekerjaan akan terasa ringan bila dikerjakan saling mendukung dalam arti yang positif.” (Sabtu, 09/03/2019 Pukul 09.30 Di Kantor Pos Subang)

Dari pernyataan di atas bahwa hasil kerja akan memuaskan jika telah ada sasaran tugas dan juga dapat dilaksanakan dalam kurun waktu tertentu. Jika dalam mengambil keputusan seorang manajer selalu berhubungan dengan pekerjaan dan tegas dalam mengambil keputusan agar tidak terjadi keraguan pada staff nya sehingga staff akan memiliki rasa bertanggung jawab atas pekerjaan yang telah dikerjakannya. 
Selain itu juga penulis mewawancarai salah satu pegawai di bidang pelayanan, kualitas yang dimiliki oleh karyawan di bidang pelayanan Kantor Pos Subang, munurut informan yang menduduki jabatan sebagai Pegawai di Bidang Pelayanan, mengatakan bahwa:

"Tidak dapat dipungkiri sih, iya sih kadang kalo bagi saya sendiri jadi bahan pertimbangan juga jadi kalo misalkan ada selisih atau apa, kan pasti financial kita sendiri gitu kaya uang gaji kita sendiri juga berpengaruh buat keluarga juga kan apalagi kalo misalakan yang udah berkeluarga, kalo misalkan yang belum juga, tapikan tetep ada kaya untuk ngasih ke orang tua pasti kan ada keterkaitannya gitu. Peran aktif para pegawai di sini sih biasanya seperti harus responsibility tinggi misalkan kayak harus peka terhadap kalo fit day kami karna saya pelayanan jadi harus peka terhadap pelayanan, peka terhadak konsumen, misalkan konsumen maunya apa trus ya pokonya harus kita bimbing lah." (Sabtu, 09/03/2019 Pukul 14.04 Di Kantor Pos Subang).

Dari pernyataan tersebut tentunya berbeda dengan pernyataan yang telah disampaikan oleh Kepala Pos Kantor Pos Subang dan Manajer Bagian Pelayanan, karena pegawai tersebut mengatakan jika dalam mengambil keputusan terkadang berhubungan dengan hal yang ada di luar pekerjaan meskipun awalnya terjadi karena suatu hal yang ada di dalam pekerjaan tersebut.

Selanjutnya juga penulis wewancarai masyarakat yang sedang melakukan transaksi di Kantor Pos Subang, menurut sodari lis mengenai kualitas hasil kerja pegawai di bidang pelayanan, mengatakan "Baik, tiap kesini juga enak dan kepuasan ya 100\% bagus soalnya tiap kesini enak gitu pelayanan nya bagus" (Sabtu, 09/03/2019 Pukul 10.53 Di Kantor Pos Subang), kemudian menurut informan bernama Diana mengenai kualitas hasil kerja pegawai di bidang pelayanan, mengatakan "Baik dan Puas" Sabtu, 09/03/2019 Pukul 10.57 Di Kantor Pos Subang), kemudian menurut informan bernama Sugiato mengenai kualitas hasil kerja pegawai di bidang pelayanan, mengatakan "Baik dan Puas" Sabtu, 09/03/2019, Pukul 10.58 Di Kantor Pos Subang), selanjutnya menurut infoman bernama Radi mengenai kuantitas hasil 
kerja pegawai di bidang pelayanan, mengatakan "Kalo berkaitan untuk pos nya sendiri kan jarang sekarang, paling banyak di pelayanan pembayaran itu ya cukup” Sabtu, 09/03/2019, Pukul 11.01 Di Kantor Pos Subang), dan menurut informan bernama Dedeh mengenai kuantitas hasil kerja pegawai di bidang pelayanan, mengatakan "Alhamdulillah udah baik dan Tidak ada hambatan, lancar maksudnya".

Dari pernyataan-pernyataan diatas dapat dianalisa mengenai kualitas hasil kerja pegawai di Kantor Pos Subang belum bisa dikatakan baik karena adanya pegawai belum mampu menjaga sikap dengan baik, sehingga masalah pekerjaan dengan masalah pribadi menjadi campur aduk hal ini akan mempengaruhi interaksi dan komunikasi dengan pegawai lainnya. Meskipun menurut masyarakat baik akan tetapi tentunya itu akan menghambat suatu pekerjaan.

3) Jangka waktu untuk mencapai hasil kerja tersebut

Dalam mengerjakan tugas-nya tentunya para pegawai seharusnya dapat memanfaatkan waktunya dengan baik, menyelesaikan tugas dengan cepat dan bekerja lebih keras. Berikut penulis lampirkan hasil wawancara penulis dengan beberapa informan. Jangka waktu yang dapat dicapai dalam melakukan pekerjaan oleh pegawai di bidang pelayanan Kantor Pos Subang, munurut informan yang menduduki jabatan sebagai Kepala Kantor Pos Subang, mengatakan bahwa:

"Dari sisi waktu kita bekerja sesuai dengan ketentuan, kita bekerja tujuh sampai delapan jam dalam melayani dan menjual di loket. Sebetulnya kalo mencapai target karena di loket ini work ini cutomer jadi menunggu yang datang untuk memenuhi target adalah hal yang harus dilakukan oleh petugas itu adalah melakukan penjualan abselling atau procelling sehingga di situ ada target komulatif akan tercapai." Senin, 25/03/2019, Pukul 08.17, Di Kantor Pos Subang). 
Jangka waktu yang dapat dicapai dalam melakukan pekerjaan oleh pegawai di bidang pelayanan Kantor Pos Subang, munurut informan yang menduduki jabatan sebagai Manajer Bidang Pelayanan, mengatakan bahwa:

"Suatu pekerjaan yang kita kerjakan harus sesuai dengan waktu yang telah kita tentukan sehingga pekerjaan itu terarah, tidak tertunda-tunda hingga menumpuk dengan pekerjaan lainnya.laporan-laporanpun harus selesai dengan waktu yang sudah ditentukan, sehingga dapat menghasilkan pekerjaan yang baik juga, sehingga jika pekerjaan yang lain datang kembali sehingga langsung kita atasi." (Sabtu, 09/03/2019, Pukul 09.30, Di Kantor Pos Subang).

Jangka waktu yang dapat dicapai dalam melakukan pekerjaan oleh pegawai di bidang pelayanan Kantor Pos Subang, munurut informan yang menduduki jabatan sebagai Pegawai di Bidang Pelayanan, mengatakan bahwa:

"Iya, misalkan kan kita punya jam setiap pekerjaan kan ada jam kerjanya nah gitu misalkan kaya jam 3 nih beli materai harus ditutup terus setoran jam 3 harus, karena itu tuh saling keterkaitan antar pelayanan, sama keuangan itu emang ada keterkaitannya gitu.” (Sabtu, 09/03/2019, Pukul 14.04, Di Kantor Pos Subang).

Selain itu juga penulis wewancarai masyarakat yang sedang melakukan transaksi di Kantor Pos Subang, menurut sodari Iis mengenai Jangka waktu yang dapat dicapai dalam melakukan pekerjaan oleh pegawai di bidang pelayanan Kantor Pos Subang, munurut informan yang menduduki jabatan sebagai Pegawai di Bidang Pelayanan, mengatakan "Cepat sih, kalo banyak ya nunggu giliran gitu aja, kalo sedikit mah cepet terus enak banyak senyum gitu melayaninya, jadi pengen kesini lagi” (Sabtu, 09/03/2019, Pukul 10.53, Di Kantor Pos Subang), kemudian menurut informan bernama Diana mengenai Jangka waktu yang dapat dicapai dalam melakukan pekerjaan oleh pegawai di bidang pelayanan Kantor Pos Subang, mengatakan "Iya, cepat” (Sabtu, 09/03/2019, Pukul 10.57, Di Kantor Pos Subang), kemudian menurut informan bernama Sugiato mengenai Jangka waktu yang dapat dicapai dalam 
melakukan pekerjaan oleh pegawai di bidang pelayanan Kantor Pos Subang, mengatakan “Cepat, cukup cepat” (Sabtu, 09/03/2019, Pukul 10.58, Di Kantor Pos Subang), selanjutnya menurut infoman bernama Radi mengenai Jangka waktu yang dapat dicapai dalam melakukan pekerjaan oleh pegawai di bidang pelayanan Kantor Pos Subang, mengatakan “Cukup" Sabtu, 09/03/2019, Pukul 11.01, Di Kantor Pos Subang), dan menurut informan bernama Dedeh mengenai Jangka waktu yang dapat dicapai dalam melakukan pekerjaan oleh pegawai di bidang pelayanan Kantor Pos Subang, mengatakan "Ya pelayanannya cukup, ya kan maksudnya kan kalo cepet teh kalo namanya juga kalo ada konsumen mah suka rada ini ya soalnya kan banyak konsumen yang namanya juga antrian ya pastilah segitu mah cukup" (Sabtu, 09/03/2019, Pukul 1103, Di Kantor Pos Subang),

Dari pernyataan-pernyataan di atas maka dapat dianalisis bahwa Jangka waktu yang dapat dicapai dalam melakukan pekerjaan oleh pegawai di bidang pelayanan Kantor Pos Subang sudah cukup cepat dan cukup baik dalam melayani masyarakat yang sedang melakukan transaksi.

\section{4) Kehadiran}

Kehadiran pegawai tentunya sangat penting, jika pegawai memiliki tingkat kehadiran yang baik tentunya pegawai tersebut memiliki sumber daya yang sangat efisien di dalam pekerjaannya.

Berikut penulis lampirkan hasil wawancara penulis dengan beberapa informan. Kehadiran dan kegiatan selama hadir di tempat kerja yang dilakukan oleh pegawai di bidang pelayanan Kantor Pos Subang, munurut informan yang menduduki jabatan sebagai Kepala Kantor Pos Subang, mengatakan bahwa: 
"Kalo ketidakhadiran itu sudah ada ketentuan, mereka ada berhak cuti, ada berhak untuk tidak masuk itu karena cuti tahunan atau alasan penting sakit apalagi kalo sudah persentase, persentase nya begini kita untuk cuti tahunan kan bisa mengatur kalo kepentingan pun sebenarnya bisa diatur juga, kalo sakit mungkin tidak bisa, jadi sangat realatif dari tingkat persentase kehadiranya dari lima loket mungkin dalam sebulan ya satu bisa yang tidak hadir, satu atau dua hari lah paling banyak. Jadi, dari lima orang dalam waktu satu bulan paling lama dua hari karena itu pun bisa mengambil cuti tahunan atau cuti sakit. Kalo keterlambatan itu relatif, karena kita sudah menentukan kedatangan itu jam 7.30 itu sudah mulai pelayanan ditarik mundur 15 menit sebelum pelayanan mereka harus siap datang. Rata-rata keterlambatan itu paling 5 menit. Jadi gini untuk kegiatan temen-temen di pelayanan selain menjual itu aktivitas intinya ya, sementara aktifitas tambahannya, misalkan setiap hari sabtu kita lakukan briefing, senam kemudian ada pembinaan jasmani dan rohani, kemudian setiap sabtu atau dua kali perminggu pagi pagi sebelum melakukan pekerjaan itu ada briefing, briefing ini digunakan untuk membentuk karakter supaya lebih aktif lagi dalam hal melayani dan menjual." (Rabu, 25/03/2019, Pukul 08.17, Di Kantor Pos Subang).

Kehadiran dan kegiatan selama hadir di tempat kerja yang dilakukan oleh pegawai di

bidang pelayanan Kantor Pos Subang, munurut informan yang menduduki jabatan sebagai

Manajer Bidang Pelayanan, mengatakan bahwa:

"Kalo pegawai ketidakhadiran, kalo PT. Pos itu ya pegawai tidak ada yang tanpa izin, semuanya sudah terbiasa dengan displin, karna PT. Pos sudah ditanamkan dari pertama bekerja akan melaksanakan pekerjaan dengan sungguh-sungguh dan dilarang mangkir. Nah itu sudah rasanya jarang sekali ya pegawai pos yang mangkir, karena sanksi nya berat kalo sudah mangkir. Jadi ketidakhadiran pegawai minimal memberikan kabar by phone trus kemudian nanti dikirim surat izin menyusul. kalo kita pegawai pos ya, kita seharusnya bekerja 15 menit hadir sebelum jam kerja dimulai dan itu sudah dilaksanakan oleh semua pegawai yang ada di sini, jadi jarang sekali ya melihat keterlambatan ataupun telata lama gitu sehingga bagian yang lain ada kekosongan pegawai gitu." (Sabtu, 09/03/2019 Pukul 09.30 Di Kantor Pos Subang).

Dari pernyataan tersebut bahwa dalam kehadiran sudah ada ketentuan yang memperbolehkan untuk tidak masuk kerja dengan alasan mengambil cuti tahunan dan jika ada izin dengan alasan sakit atau keperluan keluarga dengan maksimal 2 hari tidak masuk kerja. Pegawai seharusnya 15 menit sebelum jam kerja dimulai harus sudah siap di tempat kerja. Dan keterlambatan yang sering terjadi itu sekitar 5 menit. Adapun kegiatan pegawai di bidang pelayanan selain menjual juga ada briefing, senam dan pembinaan jasmasi dan rohani. 
Kehadiran dan kegiatan selama hadir di tempat kerja yang dilakukan oleh pegawai di bidang pelayanan Kantor Pos Subang, munurut informan yang menduduki jabatan sebagai Manajer Bidang Pelayanan, mengatakan bahwa:

"Kalo saya sendiri belum pernah kalo tanpa izin, ya paling sakit atau izin. Kalo izin enggak sih paling ngambil mislakan kita tukeran dinas kaya misalkan ada dinas minggu kan, kebagian dinas minggu nah biasanya kalo dinas minggu tuh dapet jatah sehari pengganti libur, nah paling itu aja. Jadi emang ngambilnya jatah libur bukan tanpa izin kan kalo kayak gitu. Paling 5 menit kalo misalkan tanpa alasan, kalo misalkan ada alasan sih tergantung kebijakan manajernya gimana sama SDM." (Sabtu, 09/03/2019 Pukul 14.04 Di Kantor Pos Subang).

Dari penyataan-pernyaatan di atas dapat dianalisis bahwa kehadiran dan kegiatan selama hadir di tempat kerja yang dilakukan oleh pegawai di bidang pelayanan Kantor Pos Subang, dalam segi kehadiran masih belum baik karena masih ada keterlambatan pegawai dalam melakukan pekerjaan, dan kegiatan yang telah dilakukan sudah baik. Hal ini sejalan dengan observasi penulis dimana masih ada pegawai yang terlambat lebih dari 5 menit dari jam kerja dimulai.

5) Kemampuan Berkerjasama

Kesedian berkejasama dengan orang lain atau sesama pegawai di suatu instansi atau perusahaan merupakan salah satu cara untuk mencapai tujuan bersama. Hakikatnya di dalam sebuah instansi dibutuhkan kerjasama (teamwork) agar tercipta sebuah harmonisasi dalam pekerjaan untuk tercapainya sebuah tujuan yang telah ditetapkan.

Berikut penulis lampirkan hasil wawancara penulis dengan beberapa informan. Kemampuan bekerjasama dilakukan oleh pegawai di bidang pelayanan Kantor Pos Subang, munurut informan yang menduduki jabatan sebagai Kepala Kantor Pos Subang, mengatakan bahwa: 
"Perusahaan kita ini kan ada jaringan kantor antar kantor itu jangan sampai terputus kemudian dari internal sendiri di lingkungan Kantor Pos Subang antar bagian pun harus melakukan kordinasi dan komunikasi lebih kuat. Kerjasama mutlak harus dilakukan kemudian komunikasi mutlak harus dilakukan karna satu transaksi di depan, misalkan transaksi kurir itu kan ada proses lanjutan. Jika tidak berkerjasama atau tidak berkordinasi dengan bagian proses disitu akan terjadi mis terjadilah kegagalan dalam proses berikutnya. Bisa saja harusnya diserahkan jam bukan waktunya karena tidak ada komunikasi sehingga ada terjadi keterlambatan. Nah disini sangat-sangat kuat dan mutlak harus dilakukan antar bagian dalam berkomunikasi dan berkerjasama. Harus efektif, karena di sini terkait dengan waktu. Jadi, bagaimana rentang waktu yang bisa digunakan dalam suatu proses pekerjaan itu bisa nyambung dan bisa terkoneksi dengan bagian yang lainnya. Jadi, efektivitas itu harus tetep menjadi perhatian tersendiri bagi suatu bagian dalam bekerja. Di situ ada linknya, ada link koordinasi. Jadi dari struktur organisasi itu sudah ada link komunikasi dan koordinasi sehingga apapun yang terjadi pada saat pelaksaan pekerjaan selalu diterkomunikasikan baik dengan atasan ataupun bawahan." Rabu, 25/03/2019, Pukul 08.17, Di Kantor Pos Subang).

Kemampuan bekerjasama dilakukan oleh pegawai di bidang pelayanan Kantor Pos

Subang, munurut informan yang menduduki jabatan sebagai Manager Bidang Pelayanan, mengatakan bahwa:

"Kerjasama sangat diperlukan sekali ya dalam kita bekerja, karna kita bekerja tidak hanya sendiri denga yaitu bekerja seperti berkolompok ada dibagian ini, bagian A, bagian B. Nah manajemen memberikan kerjasama baik antar karyawan dengan atasan, atasan dengan bawahan. Karna atasan pun tidak bisa bekerja sendiri tanpa bantuan dari bawahan, harus saling mendukung dari staff juga. Ya, hubungan kerja secara efektif adalah dasarnya hubungan yang baik dengan rekan kerja adalah mengutamakan komunikasi yang solid. Nah komunikasi ini harus sesalu kita jaga ya, artinya atasan menyampaikan ke bawahan dengan bijak dan atasan juga menerima masukan-masukan dari bawahannya yang nantinya akan disaring dan dipilah dalam mengambil keputusan sebagia seorang pemimpin. Menjaga hubungan yang baik itu sangat penting ya sangat diperlukan juga karna tidak semua atau tidak semene-mena memerintah pegawai atau stafnya dengan seenaknya, sudah ada porsi atau job yang sudah diberikan masing-masing pegawai atau staff." Sabtu, 09/03/2019, Pukul 09.30, Di Kantor Pos Subang). 
Kemampuan bekerjasama dilakukan oleh pegawai di bidang pelayanan Kantor Pos Subang, munurut informan yang menduduki jabatan sebagai Pegawai di Bidang Pelayanan, mengatakan bahwa:

"Disini cukup solid, jadi ada satu saling membantu misalkan antar bagian tuh saling keterkaitan. Jadi, pasti ada apayabukan bantuan tangan misalkan keterkaitannya begitu erat karena setiap bagian itu perannya tersendiri gitu, mislakan kalo misalkan saya walaupun saya ini pelayanan tapi kita ngebantuin pensiuanan gitu, yang penting tujuan dari perusahaannya tercapai. Menurut saya efektif, bekerja sesuai porsinya, bekerja sesuai waktu, target. Kalo untuk saya sih di bagian pelayanan sama manajer saya sendiri sangat solid jika ada bantuan gitu kami saling apaya saling membutukan, saling melengkapi. Dimana ada bantuan kita harus cekatan gitu." (Sabtu, 09/03/2019, Pukul 14.04, Di Kantor Pos Subang).

Dari pernyataan-pernyataan di atas maka dapat dianalisis bahwa kemampuan bekerjasama pegawai di Kantor Pos Subang yang terjalin sudah baik, baik itu dengan pimpinan ataupun sesama pegawai tidak adanya. Sebaiknya hubungan kerjasama yang terjalin antara pegawai dengan pimpinan maupun sesama pegawai saat ini harus tetap dijaga dan lebih ditingkatkan lagi agar tujuan dari instansi tersebut dapat tercapai dengan baik. Dimana pegawai maupun atasan telah melakukan kerjasama yang efektif dan kerjasama yang dilakukan tersebut berpengaruh positif terhadap hasil kerja. Kerena pegawai mempunyai kemampuan untuk bekerjasama dalam menyelesaikan setiap tugas yang diberikan. hal ini sejalan dengan observasi dimana tidak adanya kesenjangan antara pegawai dengan pimpinan. Sebaiknya hubungan kerjasama pegawai dengan pimpinan tetap dijaga dan lebih ditingkatkan lagi, agar dapat mencapai visi dan misi dari instansi tersebut. 


\section{Simpulan}

Berdasarkan pembahasan hasil penelitian dari Analisis Kinerja Pegawai Di Bidang Pelayana PT. Pos Indonesia (PERSERO) Kantor Pos Subang maka dapat diambil kesimpulan, Kinerja Pegawai PT. Pos Indonesia (PERSERO) Kantor Pos Subang masih dalam kategori cukup baik karena terdapat faktor-faktor penghambat yang mempengaruhi kinerja di bidang pelayanan Kantor Pos Subang yaitu:

1. Kuantitas hasil kerja pegawai di bidang pelayanan dalam melakukan pekerjaan belum sesuai dengan target yang telah ditentukan. Hal itu tentunya akan terjadi penurunan hasil produksi dan pendapatan.

2. Kualitas hasil kerja pegawai di Kantor Pos Subang belum bisa dikatakan baik karena adanya pegawai belum mampu menjaga sikap dengan baik, sehingga masalah pekerjaan dengan masalah pribadi menjadi campur aduk hal ini akan mempengaruhi interaksi dan komunikasi dengan pegawai lainnya. Meskipun menurut masyarakat baik akan tetapi tentunya itu akan menghambat suatu pekerjaan.

3. Jangka waktu yang dapat dicapai dalam melakukan pekerjaan oleh pegawai di bidang pelayanan Kantor Pos Subang sudah cukup cepat dan cukup baik dalam melayani masyarakat yang sedang melakukan transaksi.

4. Kehadiran dan kegiatan selama hadir di tempat kerja yang dilakukan oleh pegawai di bidang pelayanan Kantor Pos Subang, dalam segi kehadiran masih belum baik karena masih ada keterlambatan pegawai dalam melakukan pekerjaan, dan kegiatan yang telah dilakukan sudah baik.

5. Kemampuan bekerjasama pegawai di Kantor Pos Subang yang terjalin sudah baik, baik itu dengan pimpinan ataupun sesama pegawai tidak adanya. Sebaiknya hubungan 
kerjasama yang terjalin antara pegawai dengan pimpinan maupun sesama pegawai saat ini harus tetap dijaga dan lebih ditingkatkan lagi agar tujuan dari instansi tersebut dapat tercapai dengan baik. Dimana pegawai maupun atasan telah melakukan kerjasama yang efektif dan kerjasama yang dilakukan tersebut ber-pengaruh positif terhadap hasil kerja. 


\section{Referensi}

Anggara, S. (2016). Administrasi Kepegawaian Negara. Bandung: CV. Pustaka Setia

D Ishak, DY Maolani, E Engkus. (2018). JISPO: Jurnal Ilmu Sosial dan Ilmu Politik 7 (2), $101-120$

Gherghina, R., Vaduva, F., \& Postole, M.A. (2009). The Performance Management In Public Institutions of Higher Education And The Economic Crisis. Annales Universitatis Apulensis Series Oeconomica, 11 (2).

Handoko, T.H. (2007). Manajemen Persero. BPFE-UGM, Yogyakarta

Hertz, J, C., \& Wetterberg, A. (2014). Akuntabilitas Sosial dalam Penyediaan Layanan Publik. Jurnal Prisma: Jurnal Pemikiran Sosial Ekonomi Vol. 33, 2014. Jakarta: LP3ES

Judge. (2011). Organizational Berhaviour: Edisi 12. Jakarta: Salemba Empat

Mangkunegara, A.P. (2005). Evaluasi Kinerja SDM, Bandung: Refika Aditama

Mahmudi. (2015). Manajemen Kinerja Sektor Publik, Yogyakarta: PP AMP YPKN

Miftah, T. (2003). Efektivitas Kerja Pegawai di Lingkungan Pegawai Negeri Sipil. LP3ES. Jakarta.

Ndraha, T. (2012). Pengantar Teori Pengembangan Sumber Daya Manusia. Jakarta: Rineka Cipta

Neuman, W. L. (2015). Metodologi Penelitian Sosial: Pendekatan Kualitatif dan Kuantitatif (terj.). Jakarta: PT. Indeks 
Notoatmojo, S. (2009). Pengembangan Sumber Daya Manusia. Jakarta: Rieneka Cipta

Rivai, V. (2003). Manajemen SDM untuk Perusahaan: Cetakan Pertama. Jakarta: Raja Grafindo Persada

Rosidah, A.T.S. (2009). Manajemen Sumber Daya Manusia konsep, Teori dan pengembangan dalam konteks organisasi Publik. Yogyakarta: Graha Ilmu

Sastrohadiwiryo, B. S. (2005). Manajemen Tenaga Kerja Indonesia (Pendekatan Administrasi dan Operasional). Jakarta: PT. Bumi Aksara cetakan ke 3 : Desember

Sedarmayanti. (2001). Manajemen Sumber Daya Manusia, Bandung: Mandar Maju

Siagian, S. (2004). Kiat Meningkatkan Produktivitas Kerja. Jakarta: Rineka Cipta

Sehendi, H., Anggara, S. (2010). Perilaku Organisasi. Bandung: CV. Pustaka Setia

Supratikno, et al. (2006). Manajemen Kinerja Untuk Menciptakan Keunggulan Bersain, Yogyakarta: Graha Ilmu.

Supriyanto, A., dkk. (2017). Mencipta Inovasi. Inovasi Untuk Pencapaian Tujuan Pembangunan berkelanjutan. Jakarta: PT. Temprint

Surjadi. (2012). Pengembangan Kinerja Pelayanan Publik. Bandung: PT. Refika Aditama.

Umam, K. (2012). Manajemen Organisasi. Bandung: CV. Pustaka Setia . (2014). Manajemen Perkantoran. Bandung: CV. Pustaka Setia

Wibowo. (2007). Manajemen Kerja Edisi 1. Jakarta: PT Raja Grafindo Persada 